\title{
Uloga Roma u demografskim resursima Međimurske županije
}

\author{
Hrvoje Šlezak \\ Osnovna škola Kuršanec, Čakovec, Hrvatska \\ e-mail: hrvoje.slezak@zg.t-com.hr
}

\begin{abstract}
SAŽETAK Rad istražuje ulogu Roma u demografskim resursima Međimurske županije. Kako Međimurska županija ima nešto povoljnija demografska obilježja od hrvatskoga prosjeka, istražuje se utjecaj Roma na određene varijable indeksa demografskih resursa. Propituje se u kolikoj mjeri Romi kao najbrojnija etnička manjina u Međimurskoj županiji utječu na vrijednosti prirodnoga kretanja njenoga ukupnog stanovništva, odnosno jesu li iznadprosječne vrijednosti nataliteta i prirodne promjene direktna posljedica demografskih obilježja romskoga stanovništva i koje implikacije iz toga proizlaze. Analizom su obuhvaćene i određene strukture romskoga stanovništva koje doprinose razumijevanju uloge Roma u demografskim resursima Međimurske županije. Dobiveni rezultati upućuju na zaključak da Romi, unatoč relativno maloj zastupljenosti u ukupnom stanovništvu, u velikoj mjeri pozitivno utječu na vrijednosti prirodnoga kretanja stanovništva Međimurske županije i njenih pojedinih općina. Etnički diferencirana obilježja prirodnoga kretanja uvjetuju etničku supstituciju stanovništva Međimurske županije. S druge strane, Romi negativno utječu na pojedina strukturna obilježja ukupnoga stanovništva. U svjetlu shvaćanja stanovništva kao demografskoga resursa određenoga prostora ukazuje se na nužnost neodgodive integracije Roma.
\end{abstract}

Ključne riječi: Romi, Međimurje, natalitet, stanovništvo, demografski resursi, prirodno kretanje.

\section{Uvod}

Demografski resursi ističu se kao važna komponenta društveno-gospodarskoga razvoja određenoga prostora. Stanovništvo predstavlja osnovni razvojni čimbenik u smislu pokretača razvojnih procesa. Ono preko kontingenta radne snage ili svoga ekonomski aktivnoga dijela pokreće proizvodnju, ali i izravno sudjeluje u potrošnji proizvedenih dobara (Živić i Pokos, 2005.; Wertheimer-Baletić, 1999.). Suvremena obilježja stanovništva Hrvatske ukazuju na naglašeno negativne demografske strukture i trendove demografskih procesa koji ce se neminovno odraziti na društvenogospodarski razvoj Republike Hrvatske (Mrđen, 2004.; Nejašmić i Toskić, 2000.; Nejašmić, 2003.; Nejašmić i Mišetić, 2004.; Nejašmić, 2008.; Wertheimer-Baletić, 2005.; 
Živić, 2003.). U svjetlu opće depopulacije Republike Hrvatske, Wertheimer-Baletić upozorava da "sadašnje demografsko stanje i budući demografski procesi koji su dugoročno determinirani zakonitošću demografske inercije, već postaju limitirajući čimbenik ukupnoga gospodarskog i društvenog razvoja" (Wertheimer-Baletić, 2005.:116).

Međimurska županija, međutim, bilježi nešto povoljnija društveno-gospodarska obilježja od hrvatskoga prosjeka. Ističe se "kao županija s najvišom dosegnutom razinom društveno-gospodarske razvijenosti, i to kako u odnosu na druge županije, tako i u odnosu na cijelu Hrvatsku", temeljeno na određenim sociodemografskim indikatorima, naročito s obzirom na opću stopu aktivnosti, indeks starenja te stopu zaposlenosti i nezaposlenosti (Živić i Pokos, 2005.:223). Jedno od istaknutijih povoljnijih demografskih obilježja Međimurske županije jesu sastavnice prirodnoga kretanja stanovništva. U odnosu na Republiku Hrvatsku Međimurje bilježi nešto više stope nataliteta, unatoč činjenici što predstavlja pogranično i emigracijsko područje (Šterc, 1983.; Nejašmić, 1996.; Nejašmić i Toskić, 2000.; Nejašmić, Bašić i Toskić, 2008.). I u slučaju hipotetske standardizirane opće stope nataliteta izračunate pod pretpostavkom ujednačene dobne strukture svih županija prema prosjeku Republike Hrvatske kao standardnoj vrijednosti, Međimurska županija također izbija u prvi plan (Nejašmić i dr., 2008.). Recentna vitalna statistika i nadalje potvrđuje postojanje viših vrijednosti pokazatelja prirodnoga kretanja stanovništva. U 2008. i 2009. Međimurje je jedna od svega četiri hrvatske županije koje su zabilježile pozitivnu prirodnu promjenu ${ }^{1}$.

Međimurska županija ima i nešto povoljniju, odnosno manje nepovoljnu dobnu strukturu od Republike Hrvatske u cjelini. Ta najsjevernija hrvatska županija ima najmanji udio staroga stanovništva, najnižu prosječnu dob i najmanji indeks starenja od svih županija Republike Hrvatske (Nejašmić, 2003., 2008.)².

Nešto povoljnija demografska obilježja Međimurske županije od hrvatskoga prosjeka daju naslutiti veću vrijednost "ljudskoga kapitala" (Nejašmić i Mišetić, 2010.:50) u službi budućega društveno-gospodarskog razvitka ovoga prostora. Uspoređujući vrijednosti sintetičnoga pokazatelja demografskih resursa, kojeg predlaže Nejašmić, navedena županija u okviru Republike Hrvatske zauzima visoko peto mjesto (Nejašmić, 2008.:162). Vrijednošću indeksa demografskih resursa ${ }^{3}$ Međimurska županija se nalazi na gornjoj granici tipa demografski oslabljenoga (regresivnoga) područja s obilježjima prosječnih demografskih resursa i stagnacijom stanovništva (Nejašmić, 2008.:163).

1 Osim Međimurske županije, prirodni porast broja stanovnika u 2008. i 2009. zabilježili su Grad Zagreb, Splitsko-dalmatinska i Dubrovačko-neretvanska županija.

2 Međimurska županija bilježi najniži indeks starenja (72,0 u 2001., 91,8 u 2011.), prosječnu dob (37,6 u 2001., 40,0 u 2011.) i udio staroga stanovništva (13,6\% 2001., 15,6\% 2011.).

3 Vrijednost indeksa demografskih resursa Međimurske županije je 99,0 (Nejašmić, 2008.). 
Kako se "razvoj demografskih resursa smatra bitnim čimbenikom općega razvoja" (Nejašmić, 2008.:160), a sa svrhom razvoja strategije regionalnoga razvoja Međimurske županije, važno je poznavati pozadinu nešto povoljnijih demografskih obilježja u odnosu na velik dio hrvatskih županija. S tim ciljem predočeni rezultati pridonose kvalitativnoj dimenziji razumijevanja demografskih struktura i procesa međimurskoga prostora. Nešto povoljnija demografska obilježja Međimurske županije zasigurno se mogu djelomično obrazložiti njenom specifičnom etničkom strukturom. Ono što Međimurje čini posebnim u odnosu prema svih ostalih županija Hrvatske jest činjenica da najbrojniju manjinsku zajednicu čine Romi. Popisom zabilježenih 2887 osoba romske etničke manjine činilo je 2001. godine 2,44\% tadašnjega stanovništva Međimurske županije. Sredinom 2010. godine, temeljem podataka Ureda državne uprave u Međimurskoj županiji, u Međimurju je živjelo oko 5500 Roma, čime se njihov udio povisio na oko $4,6 \%$ procijenjenoga broja stanovništva županije $e^{4}$.

Uzimajući u obzir postojeću etničku strukturu Međimurske županije i osobitosti, kako reproduktivnoga ponašanja romske populacije u smislu visoke rodnosti (više u Šlezak, 2010.b), tako i specifičnih društveno-gospodarskih struktura, nameće se pitanje kakva je uloga Roma u demografskim resursima Međimurske županije, te u kolikoj mjeri romsko stanovništvo utječe na vrijednosti indeksa demografskih resursa (više u Nejašmić, 2008.). Kako je za izračun navedenoga indeksa jedna od korištenih varijabli opća stopa (ženskoga) fertiliteta, od interesa je bilo istražiti u kojoj mjeri romsko stanovništvo utječe na njene vrijednosti. Zbog nepostojanja potrebitih podataka, istražen je utjecaj Roma na vrijednosti nekih drugih pokazatelja prirodnoga kretanja ukupnoga stanovništva Međimurske županije. Dobiveni rezultati odgovaraju na pitanje može li Međimurje iznadprosječne vrijednosti nataliteta i prirodnoga kretanja zahvaliti upravo romskom stanovništvu? Jednako tako, od interesa je bilo i pitanje utjecaja romskoga stanovništva na kvalitativne pokazatelje ostalih društvenogospodarskih struktura stanovništva Međimurske županije, sadržanima u izračunu indeksa demografskih resursa.

S ciljem pronalaženja odgovora na postavljena pitanja formulirane su sljedeće hipoteze:

1. Romsko stanovništvo unatoč relativno maloj zastupljenosti značajnije pozitivno utječe na pokazatelje prirodnoga kretanja ukupnoga stanovništva Međimurske županije.

2. Svojim specifičnim strukturnim obilježjima romsko stanovništvo negativno utječe na određena kvalitativna strukturna obilježja ukupnoga stanovništva Međimurske županije, poput razine obrazovanosti.

4 Procijenjeni broj stanovnika Međimurske županije temeljen na podacima popisa stanovništva 2001., vitalne statistike i migracijskog kretanja iznosi 117864 stanovnika. 
Analizirajući podatke službene vitalne statistike i dostupne podatke Ureda državne uprave u Međimurskoj županiji o broju rođene djece romske nacionalnosti, ukazuje se na značenje romskoga stanovništva u izabranim pokazateljima prirodnoga kretanja u Međimurskoj županiji u periodu 2000. - 2009. godine. Ujedno se raspravlja o mogućim posljedicama predočenih rezultata na društveno-gospodarski razvoj Međimurske županije i njenih pojedinih općina. Broj rođenih, umrlih i vitalni indeks ukupnoga stanovništva Međimurske županije i njenih administrativno-teritorijalnih jedinica službeni su podaci Državnoga zavoda za statistiku, kao i procjena ukupnoga broja stanovnika Međimurske županije za svaku pojedinu godinu u razdoblju 2003. - 2010. koja je korištena za izračun opće stope nataliteta. Za ranije razdoblje 2000. - 2002. i 2011. napravljena je procjena ukupnoga broja stanovnika, temeljena na podacima popisa stanovnika, službene vitalne statistike i podacima o migraciji stanovništva u navedenom periodu. Razlike između procijenjenoga broja stanovnika Međimurske županije i najnovijih podataka popisa 2011. (113 804 stanovnika) valja pripisati promjeni metodologije i definicije stalnoga stanovništva 5 .

Kako su podaci popisa 2001. i više nego upitne vjerodostojnosti kad je riječ o romskom stanovništvu, izračun predočenih pokazatelja za pripadnike romske manjine temeljen je na podacima Ureda državne uprave u Međimurskoj županiji o broju romskih stanovnika, te broju rođenih i umrlih osoba romske nacionalnosti u Međimurskoj županiji po gradovima i općinama. Popisom stanovništva 2001. utvrđen je broj od 2887 Roma u Međimurskoj županiji. Međutim, navedeni podatak nikako ne odgovara stvarnom stanju. Kako zbog etnomimikrije, tako i zbog činjenice da određen broj romskih stanovnika uopće nije popisan (npr. u Donjoj Dubravi nije zabilježen niti jedan Rom, iako je tamo postojalo romsko naselje sa 60-ak stanovnika), službene popisne podatke valja uzeti s velikom dozom rezerve. Istovremeno, zbog osobitosti prirodnoga kretanja romskoga stanovništva brojno stanje je značajno promijenjeno od vremena popisa 2001. Sukladno navedenom kao najvjerodostojniji podaci nameću se oni Ureda državne uprave u Međimurskoj županiji koji se temelje na podacima biračkih popisa, matičnih ureda, Centra za socijalnu skrb i Policijske uprave Međimurske županije. Vremenska serija broja stanovnika romske nacionalnosti u Međimurskoj županiji rezultat je utvrđenoga brojnog stanja u 2009. godini koje se umanjivalo za vrijednost prirodnoga kretanja romskoga stanovništva, čime je procijenjen broj romskih stanovnika za sredinu svake analizom obuhvaćene godine.

Kako etnički diferenciranih podataka o određenim strukturnim obilježjima romskoga stanovništva nema ili nisu dostupni, izračuni su se temeljili na strukturnim

\footnotetext{
5 Popisom 2011. nisu u stalno stanovništvo obuhvaćene osobe s prebivalištem u RH na radu u inozemstvu koje izbivaju više od godine dana i ne vraćaju se tjedno u mjesto prebivališta. 2001. godine bilo je 7744 osobe na radu u inozemstvu koje izbivaju više od godine dana iz mjesta prebivališta, a obuhvaćene su u stalno stanovništvo Međimurske županije. Kako su u trenutku pisanja rada podaci popisa 2011. godine još nepotpuni, tj. bez uvida u broj radnika u inozemstvu, izračuni i procjene temeljeni su na podacima popisa 2001. godine.
} 
obilježjima romskoga naselja Kuršanec, koja su pretpostavljena za ukupno romsko stanovništvo Međimurske županije ${ }^{6}$.

Zbog izrazite prostorne stabilnosti romskoga stanovništva Međimurske županije (Pokos, 2005.), migracijska komponenta koja je možebitno utjecala na kretanje broja romskih stanovnika u analiziranom razdoblju ovom je prilikom zanemarena ${ }^{7}$. Kako je i temeljem rezultata terenskoga istraživanja u romskom naselju Kuršanec utvrđeno da je međužupanijska migracijska bilanca u posljednjem desetogodišnjem periodu zanemariva $^{8}$ (Šlezak, 2010.a), a uz pretpostavku da su slična migracijska obilježja prisutna kod ostatka romskoga stanovništva Međimurja, eventualna postojeća međužupanijska migracijska kretanja romskoga stanovništva nemaju bitan utjecaj na iznesene rezultate, te iz toga razloga migracijska komponenta romskoga stanovništva ovom prilikom nije uzeta u obzir.

Predočeni pokazatelji za većinsko, etnički neromsko stanovništvo Međimurske županije izračunati su izostavljanjem broja romskih stanovnika, broja rođenih i broja umrlih romske nacionalnosti dobivenih prije navedenom metodom od vrijednosti službenih podataka za ukupno stanovništvo gradova i općina, kao i čitave Međimurske županije.

\section{Uloga Roma u prirodnom kretanju stanovništva Međimurske županije}

Pojam natalitet korišten u ovom radu odnosi se na tzv. efektivni natalitet, odnosno broj živorođene djece u promatranom prostoru tijekom jedne kalendarske godine. Natalitet je pozitivna sastavnica prirodnoga kretanja stanovništva koja u određenim okolnostima pridonosi porastu stanovništva nekoga prostora (Wertheimer-Baletić, 1999.). U Međimurskoj županiji to je bio slučaj u pet od analizom obuhvaćenih dvanaest godina. Pozitivna prirodna promjena zabilježena je 2000., 2001., 2008., 2009. i 2010. godine.

Stope nataliteta stanovništva Međimurske županije u promatranom razdoblju kretale su se u rasponu od 9,95 do 11,37\%0 (tablica 1.). Za usporedbu, stope nataliteta stanovništva Republike Hrvatske u istom vremenu kretale su se u rasponu od 8,9 do

6 Autor je 2009. godine proveo sveobuhvatni popis stanovnika romskoga naselja Kuršanec koje je drugo najveće romsko naselje u Međimurskoj županiji. Popisom je utvrđeno da u navedenom naselju živi 960 stanovnika, što je u tom trenutku predstavljalo oko 18\% ukupnoga romskog stanovništva Međimurja. Stoga naselje Kuršanec tipom naseljenosti i brojem stanovnika predstavlja reprezentativan uzorak ukupnoga romskog stanovništva Međimurske županije (vidi više u Šlezak, 2010.a).

7 Prema Pokosu (2005.) 85\% Roma u Međimurskoj županiji živi u mjestu rođenja, a iz inozemstva nije doselio niti jedan pripadnik njihove zajednice.

8 U razdoblju 2000. - 2009. međužupanijska migracijska bilanca romskoga stanovništva naselja Kuršanec iznosila je -1 stanovnika. Izvor: Šlezak, (2010.a) 
10,1\%o. Tijekom svih promatranih godina stanovništvo Međimurske županije imalo je višu stopu nataliteta od ukupnoga stanovništva Republike Hrvatske.

\section{Tablica 1.}

Romi u natalitetu stanovništva Međimurske županije 2000. - 2009.

(Roma in Medjimurje County population's Fertility 2000 - 2009.)

\begin{tabular}{|c|c|c|c|c|c|c|}
\hline Godina & $\begin{array}{c}\text { Broj } \\
\text { stanovnika } \\
\text { županije }\end{array}$ & $\begin{array}{l}\text { Ukupan broj } \\
\text { živorođenih }\end{array}$ & $\begin{array}{c}\text { Stopa } \\
\text { nataliteta } \\
(\% 0)\end{array}$ & $\begin{array}{l}\text { Vitalni } \\
\text { indeks }\end{array}$ & $\begin{array}{l}\text { Broj } \\
\text { živorođenih } \\
\text { Roma }\end{array}$ & $\begin{array}{c}\text { Romi u } \\
\text { natalitetu } \\
\text { županije } \\
(\%)\end{array}$ \\
\hline 2000. & 118306 & 1345 & 11,37 & 104,5 & 224 & 16,65 \\
\hline 2001. & 118450 & 1346 & 11,36 & 108,8 & 208 & 15,45 \\
\hline 2002. & 118466 & 1238 & 10,45 & 94,4 & 186 & 15,02 \\
\hline 2003. & 118424 & 1249 & 10,55 & 98,2 & 164 & 13,13 \\
\hline 2004. & 118371 & 1178 & 9,95 & 97,4 & 172 & 14,60 \\
\hline 2005. & 118419 & 1236 & 10,44 & 98,6 & 181 & 14,64 \\
\hline 2006. & 118231 & 1220 & 10,32 & 94,1 & 214 & 17,54 \\
\hline 2007. & 117994 & 1214 & 10,29 & 98,8 & 187 & 15,40 \\
\hline 2008. & 117923 & 1286 & 10,91 & 101,1 & 171 & 13,30 \\
\hline 2009. & 117891 & 1326 & 11,25 & 103,5 & 213 & 16,06 \\
\hline 2010. & 117890 & 1286 & 10,91 & 104,1 & \multirow{2}{*}{\multicolumn{2}{|c|}{ Bez podataka }} \\
\hline 2011. & 117873 & 1253 & 10,63 & 99,9 & & \\
\hline UKUPNO & 1418238 & 15177 & 10,70 & 100,3 & 1920 & 15,19 \\
\hline
\end{tabular}

Izvor: DZS, Ured državne uprave u Međimurskoj županiji.

Vitalni indeks, čija vrijednost pokazuje broj živorođenih na 100 umrlih osoba, u promatranom razdoblju bilježio je vrijednosti između 94,1 i 108,8 s prosjekom 100,3. Temeljem navedenoga prosjeka može se reći da je u navedenom razdoblju sta- 
novništvo Međimurske županije prirodnim kretanjem zabilježilo minimalan porast, gotovo stagnaciju. U odnosu na cjelokupno stanovništvo Republike Hrvatske, to je također iznadprosječna vrijednost.

Posebnost obilježja prirodnoga kretanja stanovništva Međimurske županije je u vrlo značajnom udjelu romskoga stanovništva u vrijednostima nataliteta i prirodne promjene cijele županije. Tijekom promatranoga razdoblja udio Roma u natalitetu Medimurske županije kretao se u rasponu od 13,13 do 17,54\%. U prosjeku za cijelo razdoblje 15,19\% rođene djece pripadnici su romske etničke skupine. Očit je vrlo značajan doprinos romskoga stanovništva u ukupnom natalitetu županije. Uzimajući u obzir udio romskoga u ukupnom stanovništvu, koji se s početnih 3,1 povisio na 4,41\% krajem promatranoga razdoblja, može se zaključiti da je romski doprinos natalitetu županije puno veći od njihove zastupljenosti u ukupnom stanovništvu. Navedeno je posljedica vrlo visokih stopa nataliteta unutar romske zajednice u Međimurju, koje rezultiraju značajnom porastu brojnosti romskoga stanovništva (Šlezak, 2010.b).

Analizirajući stope nataliteta samo romskoga stanovništva uviđa se da višestruko premašuju zabilježene vrijednosti za ukupno stanovništvo Međimurske županije. U promatranom razdoblju kreću se u rasponu između 38,50 i 60,99\%, dok prosjek za cijelo promatrano razdoblje iznosi $43,28 \%$ (tablica 2.). Navedena vrijednost viša je za oko četiri puta od prosječne stope nataliteta ukupnoga stanovništva Međimurja u analiziranom desetgodišnjem razdoblju. Iako vrlo visokih vrijednosti opće stope nataliteta, kao i drugih pokazatelja rodnosti, pokazuju trend smanjenja što ukazuje na promjene u reproduktivnom ponašanju romske zajednice (više u Šlezak 2010.b). Vitalni indeks romske populacije u promatranom razdoblju kretao se između 661,5 i 1638,5, dok je desetgodišnji prosjek 994,8. S obzirom da je vitalni indeks dobar pokazatelj smjera (bio)reprodukcije stanovništva (Nejašmić, 2005.), njegove vrijednosti u ovom slučaju ukazuju na izrazit porast broja stanovnika romske etničke skupine. Iako je u promatranom periodu došlo do smanjenja nataliteta romskoga stanovništva, zbog "kvantitativnoga koncepta planiranja obitelji" (Nejašmić, 2005.:73) u uvjetima postojećeg sustava socijalne skrbi i socijalnih davanja, za očekivati je u narednom periodu zadržavanje postojećih stopa ili njihovo tek blago smanjenje. U slučaju zadržavanja postojećih prosječnih vrijednosti stopa nataliteta i mortaliteta, romsko stanovništvo Međimurske županije udvostručilo bi se u periodu od osamnaest godina. U tom bi slučaju u roku od dvadesetak godina romsko stanovništvo doseglo udio od 10\% ukupnoga stanovništva Međimurske županije.

Analizirajući stope nataliteta i vitalni indeks većinskoga stanovništva Međimurske županije, izostavljajući romsko stanovništvo, do izražaja dolazi sasvim druga slika demografskih procesa (tablica 3.). Stope nataliteta značajno su niže u odnosu na one s uključenim romskim stanovništvom. Vrijednosti se kreću između 8,81 i 9,88\%o. Prosječna stopa nataliteta u promatranom razdoblju od 9,42\%o u potpunosti je usporediva prosječnoj vrijednosti za cijelu Republiku Hrvatsku koja je iznosila 9,45\% Daje se zaključiti da se etnički neromsko stanovništvo Međimurske županije prema ovom pokazatelju ne razlikuje od hrvatskoga prosjeka. 


\begin{tabular}{|c|c|c|c|c|c|c|c|c|}
\hline & \multicolumn{3}{|c|}{ 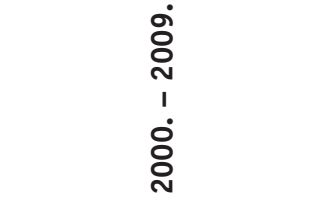 } & \multirow{2}{*}{$\begin{array}{l}\stackrel{\curvearrowright}{\curvearrowright} \\
\stackrel{\sim}{\sim}\end{array}$} & \multirow{2}{*}{ 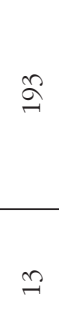 } & \multirow{2}{*}{ 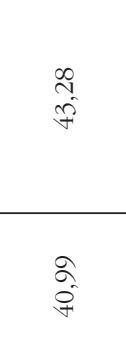 } & \multirow{2}{*}{$\begin{array}{l}\text { nn } \\
\text { fi } \\
\text { in } \\
\text { in }\end{array}$} & \multirow{2}{*}{ 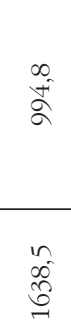 } \\
\hline & 유 & $\underset{i n}{\stackrel{2}{2}}$ & $\underset{\forall}{F}$ & & & & & \\
\hline & 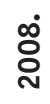 & $\begin{array}{l}\infty \\
\stackrel{\infty}{0} \\
\text { in }\end{array}$ & \begin{tabular}{l}
$\stackrel{\leftrightarrow}{~}$ \\
\multirow{f}{*}{}
\end{tabular} & $\underset{\beth}{I}$ & $\stackrel{n}{\sim}$ & $\begin{array}{l}\infty \\
0 \\
+i \\
m\end{array}$ & ๙े & $\begin{array}{l}O \\
\stackrel{+}{+} \\
\exists\end{array}$ \\
\hline & i் & $\begin{array}{l}n \\
\hat{\infty} \\
\forall\end{array}$ & $\stackrel{\mathcal{F}}{\stackrel{F}{*}}$ & 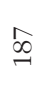 & $\vec{\sim}$ & 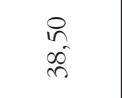 & $\underset{\forall}{\approx}$ & $\begin{array}{l}n \\
\stackrel{1}{\infty}\end{array}$ \\
\hline & $\dot{\delta}$ & \begin{tabular}{l}
$\infty$ \\
\multirow{6}{\sigma}{} \\
+
\end{tabular} & $\begin{array}{l}\stackrel{2}{n} \\
\text { nे }\end{array}$ & $\stackrel{\vec{N}}{\vec{t}}$ & $\tilde{\mathrm{N}}$ & $\begin{array}{l}n \\
\text { in } \\
\text { f }\end{array}$ & $\stackrel{R}{\stackrel{R}{*}}$ & $\begin{array}{l}\hat{i} \\
\hat{n}\end{array}$ \\
\hline बें & ㅇํㅇ & $\begin{array}{l}n \\
i n \\
i\end{array}$ & $\begin{array}{l}\infty \\
\stackrel{\infty}{1}\end{array}$ & $\underset{\infty}{\sim}$ & $\stackrel{+}{\sim}$ & $\begin{array}{l}\text { î } \\
\text { ô } \\
+\end{array}$ & $\begin{array}{l}\approx \\
n\end{array}$ & 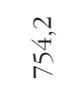 \\
\hline 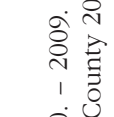 & ঠ் & $\begin{array}{l}\vec{n} \\
\hat{n} \\
\vec{v}\end{array}$ & $\begin{array}{l}\infty \\
\stackrel{\infty}{r} \\
\end{array}$ & $\stackrel{N}{\stackrel{2}{\prime}}$ & $\stackrel{i}{ }$ & $\begin{array}{l}\hat{n} \\
\hat{\tilde{n}}\end{array}$ & $\stackrel{2}{i}$ & $\frac{12}{\overrightarrow{0}}$ \\
\hline 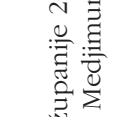 & ஜ் & 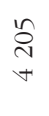 & $\begin{array}{l}i n \\
n \\
n\end{array}$ & $\stackrel{+}{\stackrel{+}{0}}$ & $\vec{\sim}$ & $\stackrel{\circ}{\hat{m}}$ & $\stackrel{\curvearrowright}{\stackrel{f}{ }}$ & $\begin{array}{l}0 \\
\infty \\
\infty\end{array}$ \\
\hline 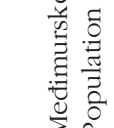 & ণั & $\begin{array}{l}\vec{b} \\
\hat{\sigma} \\
\vec{v}\end{array}$ & $\begin{array}{l}\text { f } \\
\text { ri }\end{array}$ & $\stackrel{\triangleright}{\stackrel{\sim}{\sim}}$ & $\stackrel{\curvearrowright}{二}$ & $\begin{array}{l}\vec{a} \\
\dot{\sigma}\end{array}$ & $\stackrel{\text { oे }}{f^{+}}$ & $\begin{array}{l}\hat{\infty} \\
\hat{\sigma}\end{array}$ \\
\hline 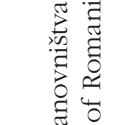 & 용 & $\begin{array}{l}m \\
\infty \\
n\end{array}$ & $\begin{array}{l}\hat{y} \\
\hat{n}\end{array}$ & $\stackrel{\infty}{\stackrel{\sim}{~}}$ & $\stackrel{\infty}{-}$ & $\begin{array}{l}\vec{\pi} \\
\hat{n}\end{array}$ & $\begin{array}{l}\text { no } \\
+\end{array}$ & $\begin{array}{l}0 \\
i n \\
\stackrel{1}{=}\end{array}$ \\
\hline 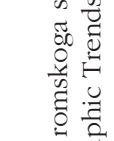 & \&̊ & $\begin{array}{l}\frac{m}{\sigma} \\
m\end{array}$ & $\begin{array}{l}\stackrel{0}{n} \\
\dot{n}\end{array}$ & $\stackrel{\mathbb{N}}{\mathbb{N}}$ & $\stackrel{ \pm}{-}$ & & $\begin{array}{l}\vec{\infty} \\
\infty\end{array}$ & $\begin{array}{l}0 \\
\stackrel{8}{0} \\
0\end{array}$ \\
\hline 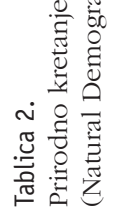 & . & 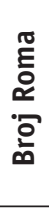 & 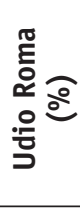 & 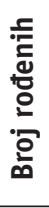 & 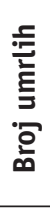 & 党蓠 & 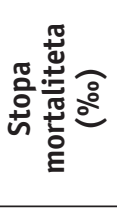 & 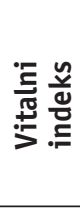 \\
\hline
\end{tabular}


Vitalni indeks etnički neromskoga stanovništva ponajviše otkriva značenje romskoga u prirodnom kretanju ukupnoga stanovništva Međimurske županije. Kad ne bi bilo Roma, Međimurska županija bilježila bi prirodni pad broja stanovnika sličnih vrijednosti vitalnoga indeksa kao i cijela Republika Hrvatska. Takav hipotetski pokazatelj kretao bi se u promatranom razdoblju između 79 i 93,4, dok bi prosječna vrijednost bila 86 .

Iz navedenoga daje se zaključiti da Romi, unatoč relativno maloj zastupljenosti, u velikoj mjeri utječu na prirodno kretanje ukupnoga stanovništva Međimurske županije. Kako je teško očekivati promjenu negativnoga trenda prirodnoga kretanja etnički neromskoga stanovništva i značajnije smanjenje prirodne promjene romskoga stanovništva, Romi će progresivno povećavati svoj udio u ukupnom stanovništvu Međimurske županije i u budućem razdoblju, naravno, uz pretpostavku da se ne dogode velike promjene u obilježjima mehaničkoga kretanja stanovništva, odnosno značajne promjene trendova migracijskih kretanja stanovništva Međimurske županije.

Tablica 3.

Stope nataliteta i vitalni indeks etnički neromskoga stanovništva Međimurske županije 2000. - 2009.

(Crude Birth Rates and Vital Index of Ethnically non Roma Population in Medjimurje County 2000 - 2009.)

\begin{tabular}{|c|c|c|c|c|c|c|c|c|c|c|c|}
\hline Godina & 2000. & 2001. & 2002. & 2003. & 2004. & 2005. & 2006. & 2007. & 2008. & 2009. & $\begin{array}{c}\text { Prosjek } \\
\mathbf{2 0 0 0 .} \\
- \\
\mathbf{2 0 0 9}\end{array}$ \\
\hline $\begin{array}{c}\text { Stopa } \\
\text { nataliteta } \\
\text { (\%o) }\end{array}$ & 9,78 & 9,93 & 9,19 & 9,50 & 8,81 & 9,26 & 8,86 & 9,08 & 9,88 & 9,88 & 9,42 \\
\hline $\begin{array}{c}\text { Vitalni } \\
\text { indeks }\end{array}$ & 88,1 & 93,4 & 81,4 & 86,7 & 84,8 & 85,8 & 79,0 & 85,0 & 88,7 & 87,8 & 86,0 \\
\hline
\end{tabular}

Izvor: DZS, Ured državne uprave u Međimurskoj županiji.

Vrlo je interesantno ulogu Roma u prirodnom kretanju proanalizirati na nižoj razini upravno-teritorijalnoga ustroja, odnosno na razini gradova i općina Međimurske županije. U administrativnim jedinicama gdje je prisutan manji broj Roma njihov je značaj u natalitetu vrlo malen, gotovo zanemariv. Međutim, u općinama gdje živi veći broj Roma njihov je udio u natalitetu i prirodnom kretanju velik, puno veći od njihove zastupljenosti u stanovništvu određene administrativne jedinice (tablica 4.).

Od ukupno 25 gradova i općina Međimurske županije Romi su značajnije zastupljeni u 11 administrativnih jedinica gdje uglavnom žive u zasebnim romskim naseljima prostorno odvojeni od većinskoga stanovništva (Šlezak, 2009.). Manji broj Roma živi i u drugim općinama u kojima je njihov utjecaj na prirodno kretanje zanemariv. 
Šest općina Međimurske županije u promatranom razdoblju bilježi viši udio romske komponente nataliteta od županijskoga prosjeka (sl. 1.). Riječ je o Podturnu (16,48\%), Nedelišću (26,49\%), Kotoribi (34,92\%), Maloj Subotici (39,06\%), Pribislavcu $(44,12 \%)$ i Orehovici (46,58\%). Četiri administrativne jedinice bilježe nešto niže vrijednosti od županijskoga prosjeka: Grad Čakovec (13,76\%), Mursko Središće $(13,11 \%)$, Domašinec $(10,62 \%)$ i Donja Dubrava (14,29\%). Predočeni rezultati ukazuju da romsko stanovništvo u dobnoj skupini do 10 godina starosti obuhvaća vrlo visoke udjele u stanovništvu, kako pojedinih općina, tako i Međimurske županije u cjelini. U dvije međimurske općine, Orehovici i Pribislavcu, Romi posljednjih deset godina čine gotovo polovicu svih rođenih. To su ujedno općine s najvišim udjelom romskoga stanovništva s vrijednostima blizu 20\% iz čega i proizlazi toliki značaj u pokazateljima prirodnoga kretanja.

\section{Tablica 4.}

Romi u prirodnom kretanju stanovništva gradova i općina Međimurske županije (2000. -2009.). (Roma in Natural Demographic Trends of Cities and Municipalities in Medjimurje County (2000 - 2009))

\begin{tabular}{|c|c|c|c|c|c|c|c|c|}
\hline $\begin{array}{c}\text { Grad } \\
\text { općina }\end{array}$ & $\begin{array}{l}\text { Broj } \\
\text { rođenih }\end{array}$ & $\begin{array}{c}\text { Broj } \\
\text { umrlih }\end{array}$ & $\begin{array}{c}\text { Broj } \\
\text { rođenih } \\
\text { Roma }\end{array}$ & $\begin{array}{c}\text { Broj } \\
\text { umrlih } \\
\text { Roma }\end{array}$ & $\begin{array}{c}\text { Romi u } \\
\text { natalitetu } \\
\text { grada / } \\
\text { općine } \\
(\%) \\
\end{array}$ & $\begin{array}{c}\text { Vitalni } \\
\text { indeks } \\
\text { ukupnoga } \\
\text { stan. }\end{array}$ & $\begin{array}{l}\text { Vitalni } \\
\text { indeks } \\
\text { romskoga } \\
\text { stan. }\end{array}$ & $\begin{array}{c}\text { Vitalni } \\
\text { indeks } \\
\text { neromskog } \\
\text { stan. }\end{array}$ \\
\hline Čakovec ${ }^{*}$ & 3052 & 2571 & 446 & 44 & 14,61 & 118,7 & 1013,6 & 103,1 \\
\hline $\begin{array}{l}\text { Mursko } \\
\text { Središće }\end{array}$ & 732 & 699 & 96 & 12 & 13,11 & 104,7 & 800,0 & 92,6 \\
\hline Prelog & 721 & 872 & 0 & 0 & 0 & 82,7 & $\begin{array}{c}\text { Bez } \\
\text { pojave }\end{array}$ & 82,7 \\
\hline Belica & 296 & 435 & 4 & 0 & 1,35 & 68,0 & $\infty$ & 67,1 \\
\hline Dekanovec & 95 & 100 & 0 & 0 & 0 & 95,0 & $\begin{array}{c}\text { Bez } \\
\text { pojave }\end{array}$ & 95,0 \\
\hline Domašinec & 273 & 281 & 29 & 0 & 10,62 & 97,2 & $\infty$ & 86,8 \\
\hline $\begin{array}{c}\text { Donja } \\
\text { Dubrava }\end{array}$ & 189 & 307 & 27 & 4 & 14,29 & 61,6 & 675,0 & 53,5 \\
\hline $\begin{array}{c}\text { Donji } \\
\text { Kraljevec }\end{array}$ & 446 & 592 & 1 & 0 & 0,22 & 75,3 & $\infty$ & 75,2 \\
\hline $\begin{array}{c}\text { Donji } \\
\text { Vidovec }\end{array}$ & 122 & 207 & 2 & 1 & 1,64 & 58,9 & 200,0 & 58,3 \\
\hline Goričan & 263 & 365 & 10 & 2 & 3,80 & 72,1 & 500,0 & 69,7 \\
\hline $\begin{array}{c}\text { Gornji } \\
\text { Mihaljevec }\end{array}$ & 189 & 285 & 0 & 0 & 0 & 66,3 & $\begin{array}{c}\text { Bez } \\
\text { pojave }\end{array}$ & 66,3 \\
\hline Kotoriba & 418 & 377 & 146 & 16 & 34,92 & 110,9 & 912,5 & 77,5 \\
\hline $\begin{array}{c}\text { Mala } \\
\text { Subotica }\end{array}$ & 786 & 589 & 307 & 29 & 39,06 & 133,4 & 1058,6 & 85,5 \\
\hline Nedelišće & 1476 & 1162 & 391 & 31 & 26,49 & 127,0 & 1261,3 & 95,9 \\
\hline
\end{tabular}

*Za 2000. godinu Gradu Čakovcu pridruženi su rođeni i umrli u Pribislavcu koji je samostalna općina od 2001. godine. Pokazatelji za općinu Pribislavec izračunati za razdoblje 2001.-2009. 


\begin{tabular}{|c|c|c|c|c|c|c|c|c|}
\hline $\begin{array}{c}\text { Grad } \\
\text { općina }\end{array}$ & $\begin{array}{c}\text { Broj } \\
\text { rođenih }\end{array}$ & $\begin{array}{c}\text { Broj } \\
\text { umrlih }\end{array}$ & $\begin{array}{c}\text { Broj } \\
\text { rođenih } \\
\text { Roma }\end{array}$ & $\begin{array}{c}\text { Broj } \\
\text { umrlih } \\
\text { Roma }\end{array}$ & $\begin{array}{c}\text { Romi u } \\
\text { natalitetu } \\
\text { grada / } \\
\text { općine } \\
(\%)\end{array}$ & $\begin{array}{c}\text { Vitalni } \\
\text { indeks } \\
\text { ukupnoga } \\
\text { stan. }\end{array}$ & $\begin{array}{c}\text { Vitalni } \\
\text { indeks } \\
\text { romskoga } \\
\text { stan. }\end{array}$ & $\begin{array}{c}\text { Vitalni } \\
\text { indeks } \\
\text { neromskog } \\
\text { stan. }\end{array}$ \\
\hline Orehovica & 380 & 379 & 177 & 27 & 46,58 & 100,3 & 655,6 & 57,7 \\
\hline Podturen & 437 & 551 & 72 & 7 & 16,48 & 79,3 & 1028,6 & 67,1 \\
\hline Pribislavec & 476 & 249 & 210 & 20 & 44,12 & 191,2 & 1050,0 & 116,2 \\
\hline Selnica & 333 & 329 & 1 & 0 & 0,30 & 101,2 & $\infty$ & 100,9 \\
\hline Strahoninec & 256 & 231 & 0 & 0 & 0 & 110,8 & $\begin{array}{c}\text { Bez } \\
\text { pojave }\end{array}$ & 110,8 \\
\hline Sveta Marija & 213 & 311 & 0 & 0 & 0 & 68,5 & Bez & 68,5 \\
\hline $\begin{array}{c}\text { Sveti Juraj } \\
\text { na Bregu }\end{array}$ & 511 & 555 & 1 & 0 & 0,20 & 92,1 & $\infty$ & 91,9 \\
\hline $\begin{array}{c}\text { Sveti Martin } \\
\text { na Muri }\end{array}$ & 265 & 332 & 0 & 0 & 0 & 79,8 & $\begin{array}{c}\text { Bez } \\
\text { pojave }\end{array}$ & 79,8 \\
\hline Šenkovec & 284 & 227 & 0 & 0 & 0 & 125,1 & $\begin{array}{c}\text { Bez } \\
\text { pojave }\end{array}$ & 125,1 \\
\hline Štrigova & 244 & 438 & 0 & 0 & 0 & 55,7 & $\begin{array}{c}\text { Bez } \\
\text { pojave }\end{array}$ & 55,7 \\
\hline Vratišinec & 181 & 205 & 0 & 0 & 0 & 88,3 & $\begin{array}{c}\text { Bez } \\
\text { pojave }\end{array}$ & 88,3 \\
\hline Ukupno & 12638 & 12649 & 1920 & 193 & 15,19 & 99,9 & 994,8 & 86,0 \\
\hline
\end{tabular}

Izvor: DZS, Ured državne uprave u Međimurskoj županiji.

Slika 1.

Romi u natalitetu gradova i općina Međimurske županije 2000. - 2009.

(Roma in Births Rates of Cities and Municipalities in Medjimurje County 2000 - 2009.)

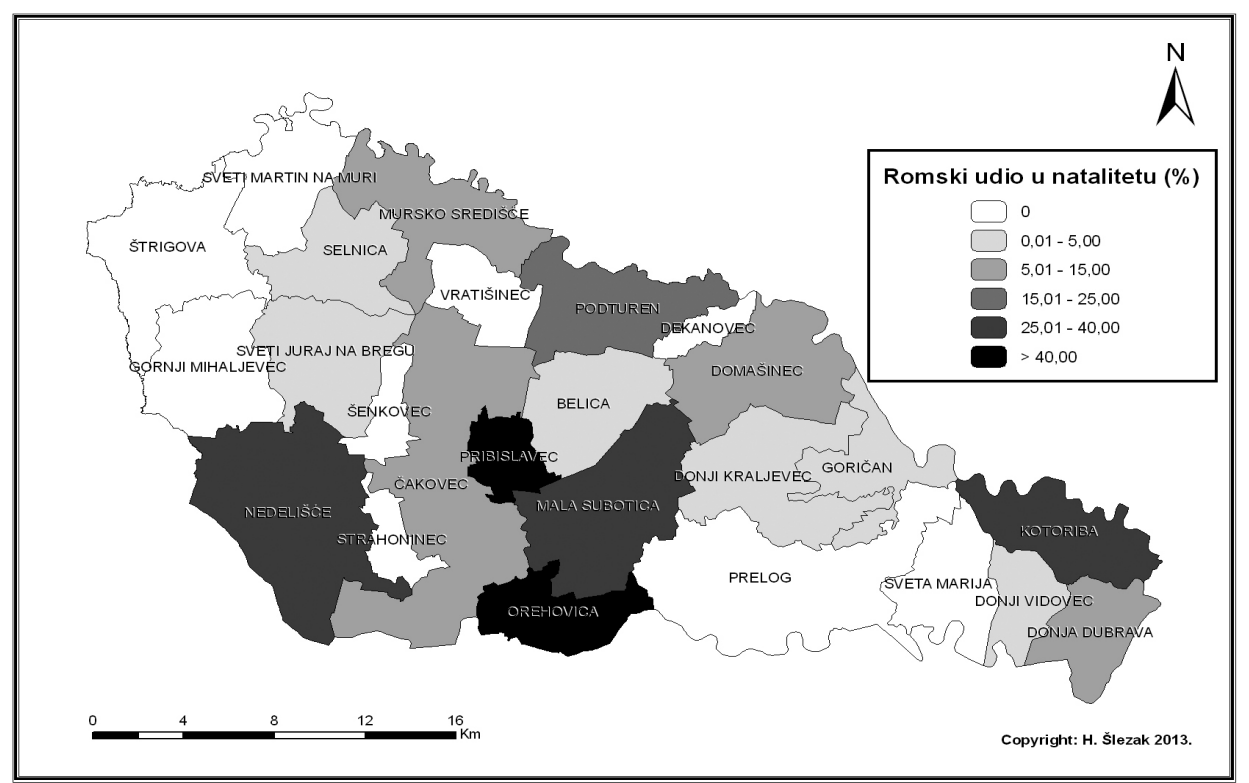

Izvor: DZS, Ured državne uprave u Međimurskoj županiji. 
Promatrajući ukupno stanovništvo, deset administrativnih jedinica u promatranom desetgodišnjem razdoblju imalo je vitalni indeks viši od 100, odnosno proširenu reprodukciju stanovništva (slika 2.). U njih sedam romsko stanovništvo u značajnoj mjeri participira u vrijednostima prirodnoga kretanja. Kada se u izračunu isključi doprinos romskoga stanovništva, pet od navedenih sedam gradova i općina imalo bi prirodan pad broja stanovnika. Jedino bi Grad Čakovec i općina Pribislavec bilježili prirodni porast broja stanovnika i u slučaju zanemarivanja utjecaja romskoga stanovništva. Prema tome, svega pet administrativnih jedinica Međimurske županije bilježi prirodni porast etnički neromskoga stanovništva: Grad Čakovec, potom prigradske općine Strahoninec, Šenkovec i Pribislavec, te općina Selnica (slika 3.), dok ostalih pet općina (Nedelišće, Orehovica, Mala Subotica, Kotoriba i Mursko Središće) svoj prirodni porast broja stanovnika mogu zahvaliti isključivo romskom stanovništvu. Takva je situacija pogotovo naglašena u Orehovici gdje romsko stanovništvo utječe na pozitivnu prirodnu promjenu broja stanovnika općine, dok bi u slučaju izostavljanja romske komponente općina bilježila vrlo izražen prirodni pad broja stanovnika s vitalnim indeksom 57,7 .

Slika 2.

Vitalni indeks gradova i općina Međimurske županije 2000. - 2009.

(Vital Index of Cities and Municipalities in Medjimurje County 2000 - 2009.)

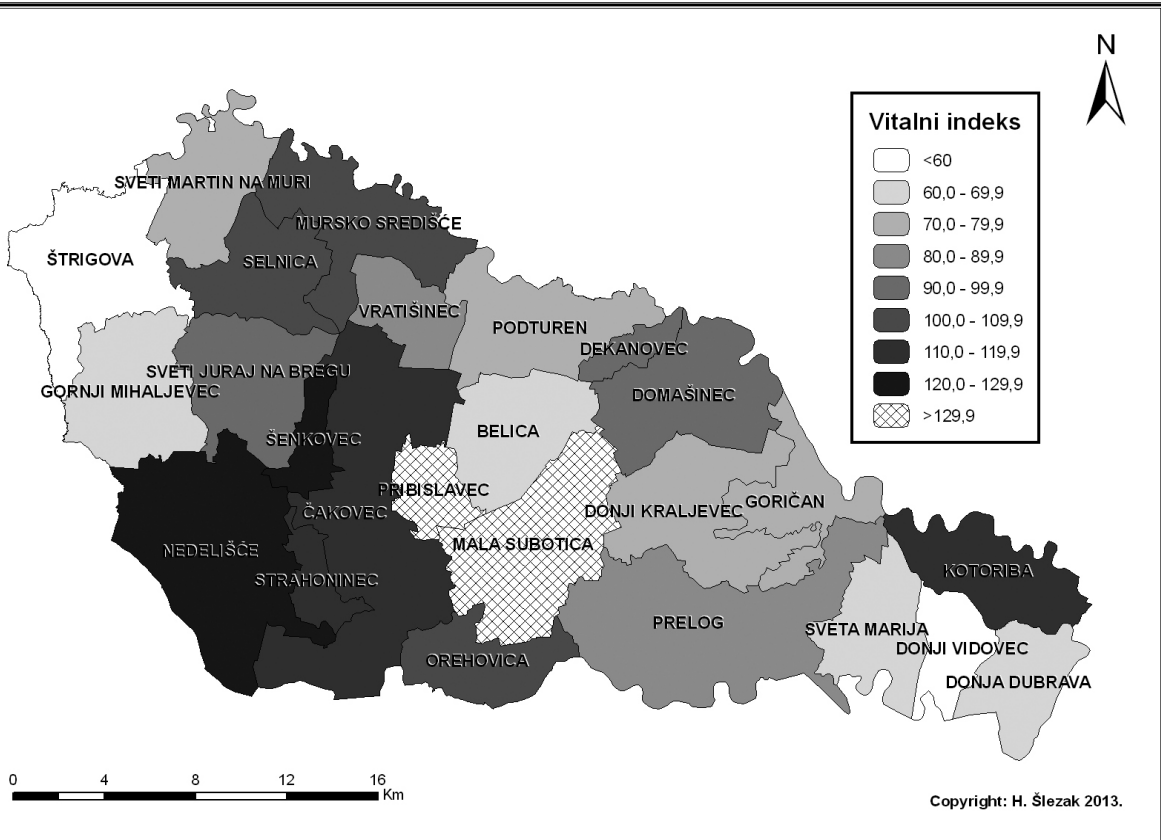

Izvor: DZS, Ured državne uprave u Međimurskoj županiji.

U općinama gdje je unatoč prisutnosti Roma zabilježen prirodni pad broja stanovnika, situacija bi bez njih bila kudikamo lošija. Uočava se da Romi svugdje gdje su prisutni u znatnoj mjeri pridonose povišenju vrijednosti promatranih pokazatelja, 
odnosno umanjuju negativna demografska obilježja pojedinih gradova i općina, kao i cijele Međimurske županije.

Predočeni rezultati ukazuju na značajan utjecaj romske etničke manjine na promjene u demografskom razvoju Međimurske županije u smislu povećanja udjela romskoga stanovništva u demografskim strukturama i procesima, čime je potvrđena prva postavljena hipoteza. Dok na razini cijele Republike Hrvatske negativni demografski trendovi u budućem dvadesetogodišnjem razdoblju mogu biti ublaženi eventualnom imigracijom (Mrđen, 2004.), Međimurska županija može očekivati manje nepovoljne demografske trendove zahvaljujući romskom stanovništvu. Povećanjem broja pripadnika romske zajednice, uz zadržavanje postojećih visokih stopa njihovoga nataliteta i prirodnoga priraštaja, uz pretpostavku da ne dođe do značajnije imigracije etnički neromskoga stanovništva, povećat će se i utjecaj te etničke skupine na demografske pokazatelje cijele Međimurske županije.

\section{Slika 3.}

Vitalni indeks gradova i općina Međimurske županije s isključenom romskom komponentom 2000. - 2009.

(Vital Index in Cities and Municipalities of Medjimurje County with Excluded Roma Component 20002009.)

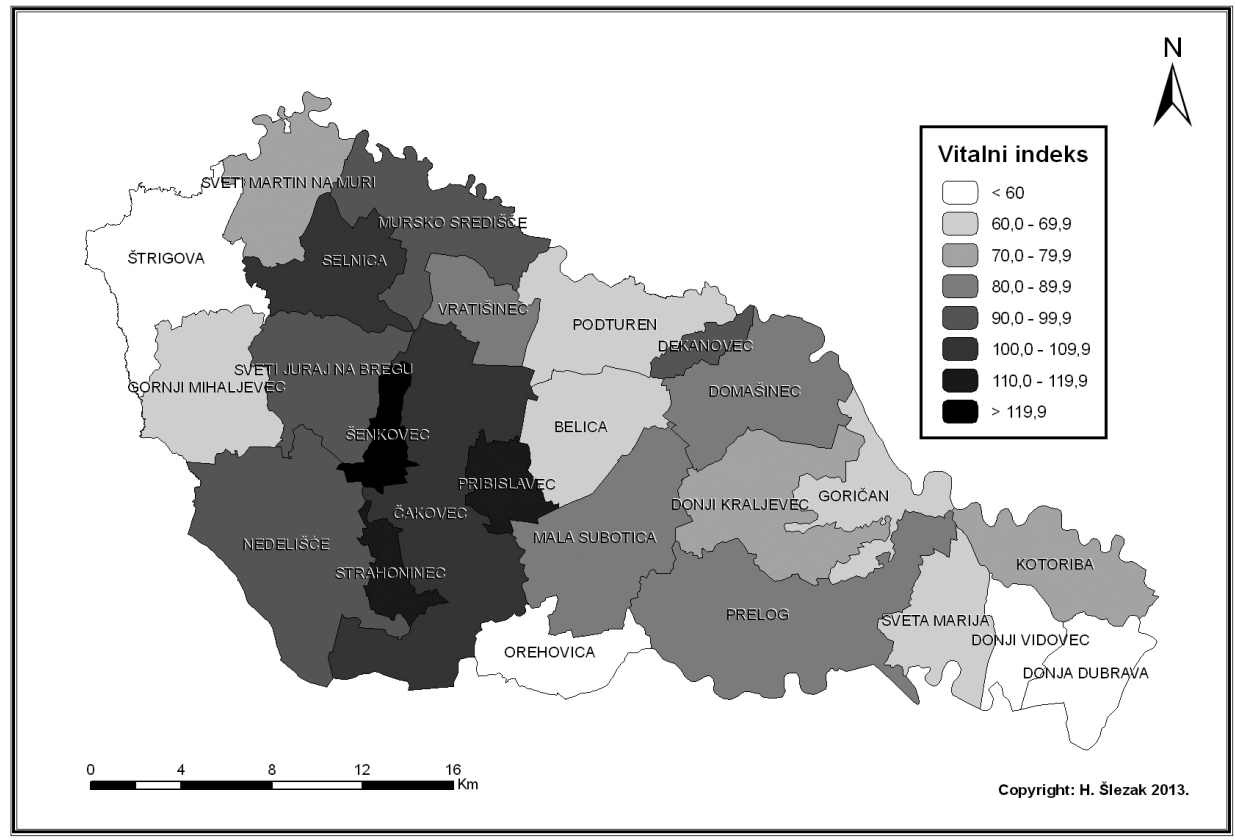

Izvor: DZS, Ured državne uprave u Međimurskoj županiji.

Navedeni rezultati ukazuju na pojavu etničke supstitucije stanovništva Međimurske županije i njenih pojedinih općina. Pomalo, ali sigurno, romsko stanovništvo povećava svoj udio na račun etnički neromskoga stanovništva. Prvi puta u novijoj hrvatskoj povijesti jedan dio Republike Hrvatske u relativno kratkom vremenu mijenja svoju etničku strukturu prirodnim demografskim procesima. Dok su sve 
dosad zabilježene etničke strukturne promjene bile posljedica migracijskih kretanja uzrokovanih različitim društvenim, gospodarskim ili političkim razlozima, Međimurska županija bilježi promjenu etničke strukture temeljene na etnički diferencijalnim obilježjima prirodnoga kretanja stanovništva. Zbog visokoga prirodnog prirasta romskoga stanovništva i prirodnoga pada većinskoga, etnički neromskoga stanovništva, etnička struktura Međimurske županije mijenja se u smislu stalnoga povećavanja udjela romskoga stanovništva. Unatoč upitnosti vjerodostojnosti popisnih podataka, dobar pokazatelj jesu usporedni podaci o broju i udjelu romskoga stanovništva u pojedinim gradovima i općinama Međimurske županije prema popisima 2001. i 2011. godine (tablica 5.). ${ }^{\text {? }}$

Tablica 5.

Romi u gradovima i općinama Međimurske županije 2001. i 2011.

(Roma in Cities and Municipalities in Medjimurje County in 2001 and 2011.)

\begin{tabular}{|c|c|c|c|c|}
\hline Grad / općina & $\begin{array}{c}\text { Broj Roma } \\
\text { 2001. }\end{array}$ & $\begin{array}{c}\text { Udio Roma (\%) } \\
\mathbf{2 0 0 1 .}\end{array}$ & $\begin{array}{c}\text { Broj Roma } \\
\mathbf{2 0 1 1 .}\end{array}$ & $\begin{array}{c}\text { Udio Roma (\%) } \\
\mathbf{2 0 1 1 .}\end{array}$ \\
\hline Čakovec & 724 & 2,63 & 1039 & 3,83 \\
\hline Mursko Središće & 7 & 0,11 & 285 & 4,52 \\
\hline Prelog & - & - & - & - \\
\hline Belica & 6 & 0,17 & 1 & 0,03 \\
\hline Dekanovec & - & - & - & - \\
\hline Domašinec & 61 & 2,48 & 100 & 4,44 \\
\hline Donja Dubrava & - & - & 7 & 0,36 \\
\hline Donji Kraljevec & - & - & 18 & 0,39 \\
\hline Donji Vidovec & - & - & 32 & 2,29 \\
\hline Goričan & 9 & 0,29 & 42 & 1,49 \\
\hline Gornji Mihaljevec & - & - & 1 & 0,05 \\
\hline Kotoriba & 156 & 4,68 & 320 & 9,93 \\
\hline Mala Subotica & 430 & 7,58 & 694 & 12,73 \\
\hline Nedelišće & 541 & 4,69 & 1239 & 10,35 \\
\hline Orehovica & 237 & 8,56 & 491 & 18,29 \\
\hline Podturen & 173 & 3,94 & 224 & 5,78 \\
\hline Pribislavec & 381 & 13,01 & 608 & 19,39 \\
\hline Selnica & 162 & 4,71 & 1 & 0,03 \\
\hline Strahoninec & - & - & - & - \\
\hline Sveta Marija & - & - & - & - \\
\hline Sveti Juraj na Bregu & - & - & - & - \\
\hline Sveti Martin na Muri & - & - & - & - \\
\hline Šenkovec & - & - & - & - \\
\hline Štrigova & - & - & 3 & 0,11 \\
\hline Vratišinec & - & - & 2 & 0,10 \\
\hline
\end{tabular}

Izvor: DZS, popis 2001., popis 2011.

9 Značajnija razlika u broju i udjelu Roma u Murskom Središću i Selnici tijekom međupopisnog razdoblja posljedica je promjene granica općina prilikom čega je romsko naselje Sitnice izdvojeno iz općine Selnica i pripojeno Murskom Središću kamo je oduvijek i gravitiralo. 
Rast relativne zastupljenosti romskoga stanovništva brži je od njihovoga prirodnog porasta. Navedeno je posljedica činjenice da je povećanje relativnoga udjela romskoga stanovništva potencirano negativnim prirodnim kretanjem etnički neromskoga stanovništva, kao i etnički selektivne vanžupanijske migracije. Negativan županijski migracijski saldo u kome sudjeluje uglavnom etnički neromsko stanovništvo ${ }^{10}$ i njegova negativna prirodna promjena, razlog su intenzivnijega porasta relativnoga udjela romskoga stanovništva.

Pod pretpostavkom zadržavanja postojećih vrijednosti prirodnoga kretanja romskoga i većinskoga stanovništva, kao i prosječnoga županijskog migracijskog salda, Romi bi za dvadesetak godina trebali dosegnuti udio od 10\% u ukupnom stanovništvu Međimurske županije.

\section{Uloga Roma u odabranim strukturama stanovništva Međimurske županije}

Povećavanjem udjela romskoga u ukupnom stanovništvu Međimurske županije povećava se i značaj romskoga stanovništva u određenim strukturama stanovništva. S ciljem razumijevanja uloge Roma u budućem društveno-gospodarskom razvoju Međimurske županije, analiziran je i utjecaj Roma na određena strukturna obilježja. Ovom prilikom obuhvaćene su samo neke, za demografske resurse relevantne strukture: obrazovna i gospodarska struktura. Predočeni pokazatelji rezultat su terenskoga istraživanja iz 2009. godine.

\subsection{Obrazovna struktura romskoga stanovništva}

Obrazovna struktura stanovništva važna je komponenta ukupnih demografskih resursa određenoga prostora. Značajno obilježje romskoga stanovništva izrazito je niska razina obrazovanosti. Slaba naobrazba je "temeljni izvor svih romskih socijalnih, kulturnih i gospodarskih nedaća i temelj specifičnoga, prepoznatljivoga marginalnog položaja Roma" (Štambuk, 2000.:205). Velik broj nepismenih osoba koje nisu nikad pohađale neki oblik školovanja još uvijek čini znatan dio romske populacije. Tek u posljednje vrijeme zamjećuje se znatnije pohađanje i uspješnije završavanje osnovnoškolskoga obrazovanja. Završenom srednjom školom mogu se pohvaliti tek rijetki pripadnici romske zajednice, dok fakultetsku naobrazbu u Međimurskoj županiji odnedavno posjeduju svega dvije osobe romske nacionalnosti.

Vrlo nizak obrazovni sastav stanovništva jedan je od čimbenika postojanja mnogih problema unutar romske zajednice. Jedan od najistaknutijih jest neosposobljenost romskoga stanovništva za ikakav kvalificirani posao. Shodno tomu, visoka nezaposlenost djelomično je posljedica navedene niske obrazovne strukture.

10

U razdoblju 2002.-2009. migracijska bilanca Međimurske županije iznosi -467 osoba. Na uzorku romskog stanovništva naselja Kuršanec koje čini oko 20\% ukupne romske populacije u Međimurskoj županiji ustanovljena je romska županijska migracijska bilanca od -1 osobe u periodu 2000.-2008. Izvor: DZS, Šlezak, 2010.a. 
Obrazovni sastav romskoga stanovništva analiziran je na primjeru romskoga naselja Kuršanec (tablica 6.) u kojem gotovo četvrtina osoba starijih od 15 godina nikad nije pohađala školu. Zabilježen je i izuzetno visok udio osoba koje su od školovanja odustale tijekom osnovne škole, odnosno nisu je uspjele uspješno završiti. Prema tome, četiri od pet osoba nije imalo niti osnovnoškolsko obrazovanje. Tek svaki peti stanovnik romskoga naselja Kuršanec uspješno je završio osnovnu školu (20,05\%).

Tablica 6.

Obrazovni sastav stanovništva romskog naselja Kuršanec 2009. godine

(Educational Structure of Romany Population in Kursanec Settlemen, in 2009)

\begin{tabular}{|c|c|c|c|c|}
\hline $\begin{array}{c}\text { Razina } \\
\text { obrazovanja }\end{array}$ & $\begin{array}{c}\text { Nisu pohađali } \\
\text { školu }\end{array}$ & $\begin{array}{c}\text { Odustali od } \\
\text { školovanja } \\
\text { tijekom 0Š }\end{array}$ & $\begin{array}{c}\text { Završili samo } \\
\text { osnovnu školu }\end{array}$ & $\begin{array}{c}\text { Završili srednju } \\
\text { školu }\end{array}$ \\
\hline Broj osoba & 102 & 245 & 69 & 18 \\
\hline$\%$ & 23,50 & 56,45 & 15,90 & 4,15 \\
\hline
\end{tabular}

Izvor: Terensko istraživanje 2009.

Određen broj osoba u naselju Kuršanec nastavio je srednjoškolsko obrazovanje. Srednju školu dosad je uspješno završilo 18 osoba, odnosno 4,15\%. Nitko u navedenom istraživanju nije imao visoku naobrazbu niti se nalazio u sustavu visokoškolskoga obrazovanja.

Uspoređujući indeks obrazovanosti ${ }^{11}$ romskoga i ukupnoga stanovništva uočavaju se velike razlike. Dok cjelokupna županija ima vrijednost navedenoga pokazatelja 1,64, romsko stanovništvo istraživanoga naselja bilježilo je vrijednost 0,00 jer nije imalo niti jednu visokoobrazovanu osobu. Ukoliko se jedine dvije visokoobrazovane osobe romske nacionalnosti u Međimurskoj županiji "raspodijele" shodno udjelu romskoga stanovništva Kuršanca u ukupnom romskom stanovništvu županije, indeks obrazovanosti istraživanoga naselja iznosio bi 0,004 .

Iz perspektive demografskih resursa ukupnoga stanovništva, vrlo niska obrazovna struktura romskoga stanovništva negativno utječe na ukupnu obrazovnu strukturu Međimurske županije. Kako je teško očekivati značajnije poboljšanje obrazovne strukture romskoga stanovništva u kraćem vremenskom periodu, povećanjem udjela romskoga u ukupnom stanovništvu povećavat će se negativan utjecaj romskoga stanovništva na obrazovnu strukturu stanovništva županije. Stoga se kao jedino rješenje ublažavanja ovoga negativnog utjecaja nameće ulaganje u obrazovanje Roma.

11 Indeks obrazovanosti računa se formulom $I o=\frac{O_{I} \times O_{I I I}}{\left\langle O_{I} \times 10\right.}$ gdje je IO indeks obrazovanosti, $<$ OI udio stanovništva koje nema završeno primarno obrazovanje, OII udio stanovništva koje ima završeno sekundarno obrazovanje, OIII udio stanovništva koje ima završeno tercijarno obrazovanje. 
Velik broj autora ističe obrazovanje Roma kao ponajbolji put rješavanja brojnih problema i uspješnije integracije romske zajednice u hrvatsko društvo (Hrvatić, 2000.; Štambuk, 2000.; Šućur, 2000.). Svojim radovima ukazuju na nužnost boljega obrazovanja Roma i nude načine njegovoga ostvarenja. Važnost obrazovanja očituje se u upoznavanju i prihvaćanju drugačijih vrijednosnih normi. Kako ističe Ruppert sa suradnicima (1981.), obrazovne institucije predstavljaju mjesta inovacija koje se mogu pretvoriti u inovacijske procese, odnosno tokove koji su činioci stvaranja geografskoga sadržaja, tj. utječu na promjene postojećih i stvaranje novih prostornosocijalnih struktura. Škola je, prema tome, mjesto stvaranja novoga pogleda na svijet oko sebe i prihvaćanja drugačijih shvaćanja i obrazaca ponašanja. Za romsku zajednicu škola je prvo mjesto uspostave integracijskih odnosa s lokalnim stanovništvom.

\subsection{Gospodarska struktura romskoga stanovništva}

Iako gospodarski sastav stanovništva ne sudjeluje kao varijabla u izračunu indeksa demografskih resursa, u slučaju romskoga stanovništva od izrazite je važnosti. Gospodarski sastav stanovništva u pravilu se odnosi na podjelu stanovništva prema gospodarskoj aktivnosti i sastavu stanovništva prema uključenosti u određene gospodarske djelatnosti. Zbog nedostupnosti podataka potrebnih za takvu analizu, pojam gospodarske strukture ovdje se prvenstveno odnosi na sastav prema ostvarenim prihodima. Unatoč nemogućnosti prikaza pojedinih klasičnih pokazatelja gospodarske strukture stanovništva, analiza ostvarenih prihoda kućanstava nudi vrlo dobar uvid u postojeće stanje stvari.

Drugi razlog ovakve analize proistječe iz posebnosti romskoga načina privređivanja. Upravo načini privređivanja, odnosno ostvarenja prihoda, predstavljaju obilježje koje karakterizira današnji romski način života. Dohodovna struktura najvažnije je gospodarsko obilježje romskoga stanovništva. Ona je posljedica koja proizlazi iz specifičnosti načina života romskoga stanovništva.

Tablica 7.

Struktura prihoda kućanstava romskoga naselja Kuršanec 2009. godine

(Revenue Structure of Romany Households in Kursanec Settlement in 2009)

\begin{tabular}{|l|l|l|}
\hline Izvor prihoda & Broj kućanstava & \% od ukupnoga broja kućanstava \\
\hline Radni odnos & 15 & 8,57 \\
\hline Mirovina & 7 & 4,00 \\
\hline Socijalna pomoć & 159 & 90,86 \\
\hline Porodiljna naknada & 19 & 10,86 \\
\hline Dječji doplatak & 142 & 81,14 \\
\hline Povremeni rad & 124 & 70,86 \\
\hline Skupljanje sekundarnih sirovina & 14 & 8,00 \\
\hline Ostalo & 13 & 7,43 \\
\hline
\end{tabular}

Izvor: Terensko istraživanje 2009. 
Kao jedno od najistaknutijih gospodarskih obilježja romske zajednice ističe se vrlo visoka stopa nezaposlenosti. Na primjeru istraživanoga naselja stopa zaposlenosti iznosila je svega 3,78\%. Od ukupno 15 zaposlenih osoba, 14 je muškaraca. U cijelom romskom naselju zabilježena je samo jedna zaposlena osoba ženskoga spola, što ukazuje na vrlo značajnu spolnu diferencijaciju zaposlenosti romskoga stanovništva.

Ovako niska stopa zaposlenosti rezultat je više čimbenika. S jedne strane, pretpostavka je da je to posljedica određenih oblika diskriminacije tijekom zapošljavanja. S druge strane, pak, vrlo niska obrazovna struktura i osposobljenost romskoga stanovništva za obavljanje određenih poslova ograničavajući je faktor njihovom zapošljavanju. Poslovi na kojima Romi rade uglavnom su vrlo niske kvalifikacijske razine. Treći faktor, možda i najznačajniji, leži u činjenici da Romima više odgovara biti nezaposlen nego raditi. Ova činjenica može zbunjivati, međutim treba imati na umu da mnogim obiteljima različita socijalna primanja nadmašuju visinu možebitnoga dohotka koji bi ostvarivali u slučaju stalnoga zaposlenja. Najčešći oblik prihoda romskoga stanovništva jest novčana pomoć Centra za socijalnu skrb. Čak 90,86\% kućanstava ostvarivalo je ovu vrstu prihoda. Uz nju, vrlo je značajan dječji doplatak kojeg je ostvarivalo 81,14\% kućanstava. Prema tome, romsko stanovništvo gotovo u potpunosti živi od neke vrste socijalnih primanja. Zbog većega broja djece u obiteljima ukupna suma takvih primanja ponekad višestruko nadmašuje prosječan osobni dohodak njihovih zaposlenih sumještana. Postojeća socijalna politika i zakonska regulativa Republike Hrvatske generator su nastavka kvantitativnoga koncepta planiranja obitelji u romskoj zajednici. Veći broj članova obitelji, veći obiteljski dohodak.

Vrlo nisku zaposlenost romskoga stanovništva valja, stoga, gledati i u svjetlu dragovoljnoga prihvaćanja statusa nezaposlenih osoba, čime ostvaruju mnoga socijalna prava. Štoviše, nepostojanje obveze stalnoga zaposlenja otvara im mogućnost sudjelovanja u sivoj ekonomiji i povremenim poslovima. Na anketni upit o vrsti prihoda, osobe iz 124 kućanstva (70,86\%) izjavile su da prihvaćaju povremene poslove koji im se nude. U prvom redu ti se poslovi odnose na nadničarenje u poljoprivredi za lokalne poljoprivredne proizvođače. Druga glavna vrsta dodatnih prihoda od povremenih poslova odnosi se na naknadu za ostale oblike uglavnom fizičkoga rada. Romi rado sudjeluju u kratkotrajnim fizičkim poslovima kojima dodatno pridonose obiteljskom proračunu.

Jedna od čestih predrasuda o romskom stanovništvu jest bavljenje skupljanjem sekundarnih sirovina. Iako je istina da se ovom vrstom posla bave uglavnom Romi, njihov je broj zapravo malen. Svega 8\% kućanstava istraživanoga naselja ostvaruje prihod skupljanjem sekundarnih sirovina. Prema tome, u ukupnoj promatranoj populaciji broj ljudi koji se bave ovom vrstom posla nije onoliko velik kako bi se moglo očekivati.

Od ostalih vrsta prihoda valja spomenuti još i prošnju. Još uvijek određeni broj kućanstava privređuje prošnjom po okolnim selima i gradovima - Čakovcu i Varaždinu. Ostvarivanje ove vrste prihoda zabilježeno je u 7 kućanstava romskoga naselja Kuršanec, što čini 4\% ukupnoga broja kućanstava. Pretpostavka je da je taj broj ipak nešto veći jer su se pojedini ispitanici sramili iskreno odgovoriti na takvo 
postavljeno pitanje. Ono što je karakteristika ovakvoga načina privređivanja jest da u njemu sudjeluju isključivo žene i ponekad uz njih vlastita djeca. Muškarci u prošnji ne sudjeluju.

Provedena analiza dohodovne strukture ukazuje na mnoge posebnosti današnjega romskog načina života. Takva struktura prihoda, kako je navedeno na početku, posljedica je specifičnosti romske zajednice i njenoga načina življenja. Međutim, navedena struktura prihoda istovremeno predstavlja i daljnji uzrok nastavka ovakvoga načina života. Visok stupanj socijalne zaštite i ukupna vrijednost različitih socijalnih primanja u mnogim slučajevima djeluju vrlo demotivirajuće na romsku zajednicu u smislu želje za promjenom načina života. Očito je da postojeći sustav socijalne zaštite i zakonska regulativa na tom području podržava navedeni način života Roma. Ukoliko se želi potaknuti romsku zajednicu na promjene, treba krenuti od izmjene zakonske regulative socijalne politike. Trenutni način njenoga funkcioniranja ni na koji način ne potiče romsko stanovništvo na ekonomsko osamostaljivanje, aktivno traženje zaposlenja i preuzimanja odgovornosti za budućnost svoje zajednice.

U skladu s navedenim, u sadašnjoj situaciji najveći dio romskoga stanovništva predstavlja stanovništvo koje ne živi od vlastitoga rada. Povećanjem broja romskoga stanovništva povećat će se i broj stanovnika koji ovise o raznim oblicima socijalnih primanja, što je nepovoljna strukturna promjena koja utječe na društveno-gospodarski razvoj. Situacija je vrlo ozbiljna uzme li se u obzir da u dobnim skupinama do 10 godina starosti romsko stanovništvo predstavlja 15\% stanovništva Međimurske županije, dok u nekim općinama čine gotovo 50\%, poput Orehovice ili Pribislavca (tablica 4.). Kako će u bliskoj budućnosti navedeno stanovništvo ući u radno aktivnu dob, u slučaju nastavka postojeće stope nezaposlenosti romskoga stanovništva, bez obzira na njene uzroke, ono bi moglo predstavljati velik ekonomski teret, kako pojedinim gradovima i općinama, tako i Međimurskoj županiji u cjelini i nepovoljno utjecati na njihov gospodarski razvoj.

\section{Zaključak}

Kako "ukupan broj stanovnika, njegova demografska, ekonomska, društvena i druga obilježja određuju obujam i strukturu društvenih potreba” (Wertheimer-Baletić, 1999.:4) koje utječu na smjer društveno-gospodarskoga razvoja određenoga prostora, predočeni rezultati otkrivaju za budući razvoj relevantna, ali dosad zanemarivana obilježja i doprinose kompleksnijem shvaćanju stanovništva kao demografskoga resursa međimurskoga prostora. Tendencija promjene postojeće etničke strukture temeljena na demografskim procesima romskoga stanovništva koje se svojim specifičnim društveno-gospodarskim obilježjima znatno razlikuje od većinskoga stanovništva, utječe na strukturne promjene ukupnoga stanovništva Međimurske županije. Predočena etnička supstitucija stanovništva ima nepovoljan utjecaj na vrijednosti analiziranih strukturnih obilježja. Kako ističe Živić, "sve promjene i poremećaji u demografskom razvoju odrazit će se na dinamiku i smjer društveno-gospodarskoga razvoja" (Živić, 2003.:307). U ovom slučaju promjena etničke strukture imat će svoj direktan odraz na promjenu nekih drugih struktura temeljenih na specifičnostima 
romskoga stanovništva, poput obrazovne, socijalne i gospodarske strukture, što će zasigurno imati svoj odraz na društveno-gospodarski razvoj Međimurske županije. Kako ističe Wertheimer-Baletić, "ekonomski proces u velikoj je mjeri određen stupnjem aktivnosti radno sposobnoga stanovništva ili, uzeto uže, zaposlenosti radno sposobnoga stanovništva, njegovom raspodjelom na primarne, sekundarne, tercijarne i druge djelatnosti, kvalifikacijskom strukturom zaposlenih koja bitno određuje, posebno u suvremenim uvjetima gospodarskoga razvoja, veličinu i kvalitetu rezultata proizvodnje, te utječe na proizvodnost rada" (Wertheimer-Baletić, 1999.:11). U sadašnjem trenutku, u gospodarskom smislu, romsko stanovništvo, nažalost, svojim minimalnim stupnjem zaposlenosti i niskom kvalifikacijskom strukturom poništava pozitivan utjecaj na demografska obilježja ukupnoga stanovništva. Kolikogod se njihov utjecaj očituje pozitivno u smislu ukupnih demografskih pokazatelja cjelokupne Međimurske županije, to još, nažalost, u ovom trenutku ne znači kvalitetnije demografske resurse koji obuhvaćaju ukupna kvalitativna i kvantitativna, stvarna i potencijalna društvena i biološka obilježja stanovništva u određenom vremenu i prostoru (Oliveira-Roca, 1991.). Kvalitetnija demografska obilježja određenih administrativno-teritorijalnih jedinica Međimurske županije u kojima znatno participira romsko stanovništvo ne znače nužno kvalitetnije društvene potencijale njihovoga budućeg razvoja, što je posljedica specifičnih društveno-gospodarskih obilježja romskoga stanovništva u Međimurskoj županiji. U situaciji izrazitih segregacijskih i diskriminacijskih odnosa spram navedene etničke zajednice koja se vrlo teško ili nikako ne uspijeva integrirati u većinsko društvo, teško je očekivati da romsko stanovništvo u bližoj budućnosti postane ravnopravan nositelj društveno-gospodarskoga razvoja administrativno-teritorijalnih jedinica gdje su zastupljeni ili Međimurske županije u cjelini.

Kako etnički diferencirane mjere populacijske politike ne dolaze u obzir, kao jedino rješenje ublažavanja gospodarski negativnoga utjecaja romskoga stanovništva nameće se potreba hitne i neodgodive integracije romske manjine u većinsko društvo Međimurske županije. Pritom se ističe niz pojedinačnih zadataka na kojima bi valjalo inzistirati prilikom razrade mjera integracije Roma. Na prvom mjestu je bolje i uspješnije obrazovanje romske djece s ciljem razvoja kompetencija kojima bi mogli konkurirati na tržištu rada. Potom se ističe promjena dohodovne strukture romskoga stanovništva i razvoj mjera kojima bi ih se potaknulo ostvarivati prihod kroz formalne oblike rada i smanjiti ovisnost o različitim oblicima socijalnih primanja. Ništa manje važno nije utjecati na većinsko stanovništvo s ciljem smanjenja socijalne distance, stereotipa i predrasuda prema Romima, kao preduvjetom uklanjanja postojećih segregacijskih i diskriminacijskih odnosa. Tek u slučaju uspješne integracije Roma koji će na principu ravnopravnosti sudjelovati u društvenom, ali i gospodarskom životu Međimurske županije, postojeći demografski utjecaj romskoga na ukupno stanovništvo i povišenje kvalitativne strukture demografskih obilježja moći će se smatrati stvarnim demografskim resursom na kojem će se temeljiti budući društveno-gospodarski razvoj. 


\section{Literatura}

1. Hrvatić, N. (2000). Odgoj i izobrazba Roma u Hrvatskoj. Društvena istraživanja, 46-47: 267-290.

2. Mrđen, S. (2004). Projekcije stanovništva Republike Hrvatske do 2031.godine: mogu li migracije ublažiti buduće negativne demografske trendove?. Migracijske i etničke teme, 20 (1): 63-78.

3. Nejašmić, I. (1996). Regional Characteristics of Population Reproduction in the Republic of Croatia. Hrvatski geografski glasnik, 58: 1-14.

4. Nejašmić, I. i Toskić, A. (2000). Razmještaj stanovništva u Republici Hrvatskoj dio općih demografskih i društveno-gospodarskih procesa. Geoadria, 5: 93-104.

5. Nejašmić, I. (2003). Značajke biološkog (demografskog) sastava stanovništva Hrvatske. Hrvatski geografski glasnik, 65 (2): 29-54.

6. Nejašmić, I. i Mišetić, R. (2004). Buduće kretanje broja stanovnika Hrvatske: Projekcija 2001. - 2031.. Društvena istraživanja, 13 (4-5): 751-776.

7. Nejašmić, I. (2005). Demogeografija: stanouništvo u prostornim odnosima i procesima. Zagreb: Školska knjiga.

8. Nejašmić, I. (2008). Stanouništvo Hrvatske: demogeografske studije i analize. Zagreb: Hrvatsko geografsko društvo.

9. Nejašmić, I.; Bašić, K. i Toskić, A. (2008). Prostorne značajke nataliteta u Hrvatskoj. Hrvatski geografski glasnik, 70 (2): 91-112.

10. Nejašmić, I. i Mišetić, R. (2010). Sintetični pokazatelj demografskih resursa: doprinos tipologiji hrvatskog prostora. Hrvatski geografski glasnik, 72 (1): 49-62.

11. Oliveira-Roca, M. (1991). Demografski resursi regija Hrvatske: prijedlog konceptualno-metodološkog okvira istraživanja, u: Seferagić, D. (Ur.). Društvene promjene u prostoru: zbornik radova. Zagreb: IDIS.

12. Pokos, N. (2005). Demografska analiza Roma na temelju statističkih podataka, u: Štambuk, M. (Ur.). Kako žive hrvatski Romi. Zagreb: Institut društvenih znanosti Ivo Pilar.

13. Ruppert, K.; Schaffer, F.; Maier, J.; Paesler, R. (1981). Socijalna geografija. Zagreb: Školska knjiga.

14. Šlezak, H. (2009). Prostorna segregacija romskog stanovništva u Međimurskoj županiji. Hrvatski geografski glasnik, 71 (2): 65-81.

15. Šlezak, H. (2010a). Demogeografska i sociokulturna obilježja romske populacije u Medimurju (magistarski rad). Zagreb.

16. Šlezak, H. (2010b). Prirodno kretanje romskog stanovništva u Međimurskoj županiji - slučaj romskog naselja Kuršanec. Hrvatski geografski glasnik, 72 (2): $77-100$.

17. Štambuk, M. (2000). Romi u društvenom prostoru Hrvatske. Društvena istraživanja, 46-47: 197-210.

18. Šterc, S. (1983). Prirodno kretanje stanovništva prigraničja SR Hrvatske prema Mađarskoj 1961. - 1981. godine. Geografski glasnik, 45: 119-146.

19. Šućur, Z. (2000). Romi kao marginalna skupina. Društvena istraživanja, 46-47: 211-227.

20. Wertheimer-Baletić, A. (1999). Stanovništvo i razvoj. Zagreb: Mate.

21. Wertheimer-Baletić, A. (2005). Demografija Hrvatske - aktualni demografski procesi. Diacovensia, 15 (1): 97-118. 
22. Živić, D. (2003). Demografske odrednice i posljedice starenja stanovništva Hrvatske. Revija za socijalnu politiku, 10 (3-4): 307-319.

23. Živić, D. i Pokos, N. (2005). Odabrani sociodemografski indikatori razvijenosti Hrvatske i županija. Revija za sociologiju, 36 (3-4): 207-224.

\section{Izvori}

Državni zavod za statistiku, Popis stanovništva, kućanstava i stanova 31. ožujka 2001, Zagreb.

Državni zavod za statistiku, Popis stanovništva, kućanstava i stanova 31. ožujka 2011, Zagreb.

Prirodno kretanje stanovništva Republike Hrvatske 2001. - 2011., Priopćenje 7.1.1., Državni zavod za statistiku, 2002. -2012., Zagreb.

Migracija stanovništva Republike Hrvatske 2002. - 2011., Priopćenje 7.1.2., Državni zavod za statistiku, 2003. - 2012., Zagreb.

Procjena stanovništva Republike Hrvatske 2007. - 2010., Priopćenje 7.1.4., Državni zavod za statistiku, 2008. - 2011., Zagreb. 
Hrvoje šlezak

Elementary school Kuršanec, Čakovec, Croatia

e-mail: hrvoje.slezak@zg.t-com.hr

\title{
The Role of the Roma in the Demographic Resources of Međimurje County
}

\begin{abstract}
The paper explores the role of the Roma in the demographic resources of Medimurje County. Given that Medimurje County has slightly more favourable demographic characteristics than the Croatian average, the influence of the Roma on certain variables of the demographic resource index is examined. To what extent do Roma people, the largest ethnic minority in Medimurje County, affect the total population natural growth? Is the above average fertility and natural growth a direct consequence of demographic characteristics of Roma people and if so, what implications follow? The analysis includes specific structures of Roma people that contribute to understanding of the role of the Roma in demographic resources of Medimurje County. The results obtained suggest that the Roma, despite their relatively small number in the total population, largely affect the natural growth rate in Medimurje County and some of its municipalities. Ethnically differentiated characteristics of natural growth contribute to the ethnic substitution of the population of Medimurje County. On the other hand, Roma people have a negative impact on some structural characteristics of the total population. In the light of seeing the population as a demographic resource, the paper points to a growing need for urgent integration of the Roma.
\end{abstract}

Key words: Roma people, Međimurje County, birth rate, population, demographic resources, natural growth. 